\title{
14
}

\section{Driving forces behind landscape transformation in Europe, from a conceptual approach to policy options}

\author{
Jan A. Klijn ${ }^{\#}$
}

\begin{abstract}
Natural and man-induced changes modelled and remodelled European landscapes continuously. As historical and ongoing changes differ in character and intensity from time to time and from region to region whereas landscapes themselves differ in their responses, temporal and regional specification is required. From a policy point of view the questions are: i) what are the direction and rate of changes? ii) how to value these; iii) whether or not to intervene; and iv) if so, how? Options vary from compensation measures and mitigation of effects to targeting at direct influences or so-called driving forces (DFs). A co-ordinated and proactive and effective policy is mostly preferred to of a reactive policy aimed at end-of-pipe measures. To sustain conscious choices one should identify underlying causes and processes (i.e. DFs), cause-effect tracks and possibilities to intervene. The concept of driving forces is explained and elaborated, specifically for landscapes. We use two related conceptual models; the first based on the DPSIR (Driver-Pressure-State-Impact-Response) concept and - more targeted- a 'mental map' for landscape change. A third concept helps to distinguish decision-making philosophies or stages according to their scope and time horizon. Current and foreseeable trends in Europe herald major changes affecting biodiversity, cultural heritage, scenery, environmental quality and economic values. Important DFs are: i) the (largely man-induced) global change in climate and sea level rise; ii) land-use change in rural areas, related to a change in demography, technological development, geopolitical change, macroeconomic change and sociocultural changes; and iii) urbanization processes. All processes affect vast areas in Europe. We give examples for climate change and change in agriculture in Europe. Policymaking could be more effective when targeted on driving forces, though second-best strategies can be inevitable.
\end{abstract}

Keywords: driving forces; landscape; Europe; decision-making; global change; landuse change; agriculture; policy development

\section{Introduction}

Europe exhibits a stunning variety in landscape values due to a large natural diversity in climate, geology, geomorphology and biogeography enriched by a great cultural variety in land-use patterns and occupation remnants from various periods in a long history. This results in (semi-)natural biodiversity, cultural heritage (archaeology, historical land-use patterns, historical buildings), geological and

\footnotetext{
\# Alterra Green World Resarch, Landscape Europe, PO box 47, 6700 AA, Wageningen, The Netherlands. E-mail: jan.klijn@wur.nl
} 
geomorphological variety and a scenic wealth that represent emotional, aesthetic, economic, scientific and intrinsic values. These are identified by researchers, unquestioned and widely acknowledged by governments and societal institutions (Meeus, Wijermans and Vroom 1990; Bennett 1994; Council of Europe 1996; 2001; Klijn and Vos 2000; Pedroli 2000; Wascher 2000). Irrespective of this awareness and attitude, recent developments show a sometimes rapid and often irreversible decline in those values (EEA 1998; Council of Europe 1996; Delbaere 1998), related to an array of causes. In view of i) the foreseen trends in agricultural and urban land use, ii) global change and iii) the fact that international or national policies and legislative power are notably weak compared to those driving forces, expectations for coming decades are hardly reassuring. The general perception is that most measures are too late and too limited in effect. The challenging question is whether policies and intervention strategies can be shifted towards a more proactive, coordinated, powerful, effective and efficient approach targeted at the DFs themselves.

\section{What are driving forces (DFs)?}

In general system terms driving forces (synonyms: forcing factors, forcings) can be seen as independent, autonomous, 'outside' forces directly or indirectly affecting a (dependent) system (Chorley and Kennedy 1971). Those forces can either be necessary to sustain the functioning of systems in equilibrium (e.g., precipitation feeding rivers or aquifers) or cause a temporary or permanent change in its state (e.g., high amounts of precipitation causing flooding). Taking the landscape as a system, one can identify 'outside forces' responsible for landscape changes. The European Environmental Agency (EEA 2002) defines driving forces as "social, demographic and economic developments in societies and the corresponding changes in life styles, overall levels of consumption and production patterns". This definition is limited to societal processes and does not include biophysical or natural developments. Others included the latter explicitly (Turner et al. 1995). We support their broader approach. We envisage landscapes as complex and heterogeneous systems with a certain spatial and time scale (Delcourt and Delcourt 1988; Klijn 1995a), and select those forces that tend to bring about relevant changes over large regions. European landscapes differ considerably in origin, nature, geographical extent and behaviour (responsiveness, response time, vulnerability and resilience) when affected by driving forces. Consequently, system characteristics have to be specified for each landscape category. Moreover, driving forces themselves differ in origin, nature, geographical extent, duration and intensity. So specification for both driving forces and the affected systems is obligatory. We further must keep in mind that various forces can be synchronously and interactively at work and that intricate chains or even webs of cause-effect relationships exist, in which we can distinguish direct (proximal) DFs on the one hand and underlying, indirect (distant) DFs. We cannot treat cause-effect relationships as a black box when trying to indicate possibilities to intervene. An adequate analysis of mechanisms at work is necessary to pinpoint those options for interventions and assess them on feasibility (fit to the 'span of control' of decisionmakers), their effectiveness and efficiency. The above theoretical line of thinking is illustrated by two examples (see Box 1).

Both examples illustrate the fact that indirect, sometimes hardly visible or far-away causes can be detected behind the direct and better visible ones. They reveal societal and biophysical driving forces, at work 'behind the curtains'. The examples point to multiple-causal mechanisms rather than mono-causal. Underlying causes tend to have 
a longer time span and a geographically larger extent, making them harder to detect and to control than the more local and short-term events. They are experienced as autonomous forces, escaping control by local and regional administrations.

Box 1. Examples of direct and indirect Driving Forces

\begin{abstract}
Coastal erosion
An increase in storm-flood frequency, wave energy or tidal currents leads to erosion of coastal dunes. One can easily observe these direct or proximate (nearby) forces affecting the coastal landscape. The question is what underlying single force or combination of forces acts at the backstage. These could well be a change in wind force and direction and in wave energy and/or change in wave direction combined with a sealevel rise (Klijn 1990). These changes may originate from global or regional climate change related to increased production of greenhouse gases caused by a growing population and higher level of energy consumption. So, dealing with coastal erosion and policy options one has to decide what to do, where and when to be the most effective and efficient. The options vary widely from local, short-term and effectoriented sea defence works to a really global strategy to reduce the emission of greenhouse gases radically. In between these extremes intermediate strategies can be found.

\section{Land reclamation}

A farmer reclaiming a former marshland or a forested mountain slope is evidently a direct driving force causing landscape change including the risk of soil erosion or loss in biodiversity. Indirect forces could be an increased population pressure, a changing economy pushing towards market crops, the availability of capital or new technologies (e.g. mechanical equipment to cultivate formerly unattractive land) and/or a change in land-ownership or the legal system regulating land use. When there are reasons to intervene, the question is whether to focus on lessening the adverse effects or to prevent land reclamation by legal instruments or addressing the more fundamental processes.
\end{abstract}

\title{
Conceptual tools: the DPSIR model and the mental map
}

Envisaging landscapes and their changes we can state that:

- we deal with complex systems (landscapes)

- landscapes are influenced by a complex of direct and indirect DFs (often acting on larger scales than the area of study)

- DFs can be divided in regimes that bring about changes and regimes that contribute to persistence ( so necessary for their functioning)

- we have to decide if and how, when and where in the webs of causes and effects one could and should intervene.

To tackle this multiple complexity conceptual tools can assist. We present three simple models: the first is a simple DPSIR model; the second an elaboration of this model in a mental map for landscapes, whereas the third concept focuses on decisionmaking and the various levels and goals that can be reached.

\section{The DPSIR model}

The diagram in Figure 2 visualizes an elaboration of the DPSIR concept (= Driver, Pressure, State, Impact, Response model, OECD 1994; see also Wascher 2000) showing in the upper row of boxes and arrows a chain-like system of causes and effects, and in the lower row the possible interventions (= Response) acting in 
corresponding domains. Interventions can aim at purely curative strategies (far right), at the mitigation of effects or at influencing direct causes exerting pressures on the system, e.g. via land-use change, and eventually at underlying processes whether the proximal or the distant or remote forces (far left). Policy options can and should be consciously identified and deliberately chosen: an end-of-pipe type of solution (curative or mitigating measures are most common in landscape or naturemanagement measures) or more fundamentally addressing land-use changes and their DFs (i.e. source-oriented). The original DPSIR model is very general and applicable to many fields (e.g. environmental policy). There is justified criticism on its terminology and its suggested linearity, since interaction and cyclic processes form often the rule. Another point of criticism refers to the fact that policy as such could be regarded as a DF on its own instead of just a response to autonomous forces. Thirdly, various driving forces interact and sometimes reinforce each other synchronously. Keeping these points in mind we consider the DPSIR model very useful to clarify mechanisms and options to intervene.

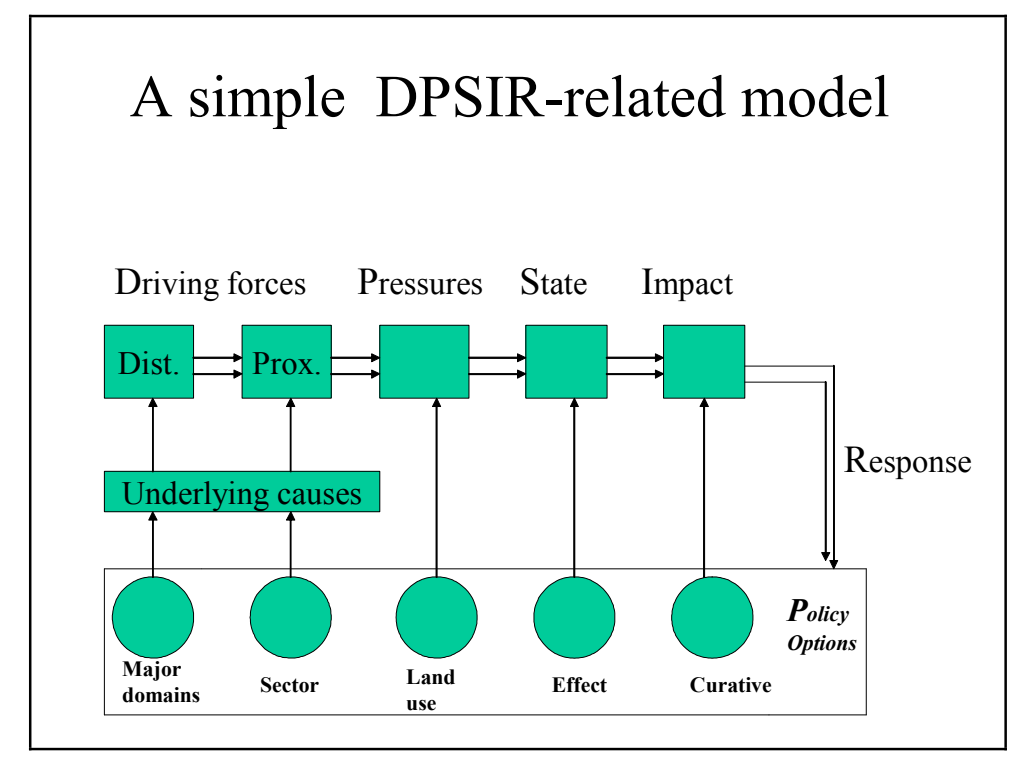

Figure 1. The DPSIR model (adapted from Posch, Hettelingh and De Smet 1997)

\section{A mental map for landscapes}

Figure 2 shows a related but more targeted conceptual model (or 'mental map') for landscapes, landscape values and driving forces as derived and slightly adapted from Klijn et al. (1999). This diagram of concentric rings puts landscapes and related values (among others ecology and cultural history) as the most dependent variables in the centre, direct influences due to land-use decisions in the following outward ring, followed by indirect, proximate and remote causes, respectively, in the next two rings of the diagram. The outer ring contains the most remote or primary DFs. A distinction has been made in natural DFs (biophysical processes such as tectonic movements, climatic change, biologically-driven processes such as succession or at a longer time scale evolution) and man-related or induced DFs, such as demography (increase, decrease or ageing of population), technology (mechanization, automation), macroeconomy (e.g. globalization tendencies), geopolitical change (e.g. the formation of the EU or the decline of the Soviet empire) and socio-cultural changes (e.g. changes in perception of nature due to scientific insights or ethical consciousness, consumption patterns).The diagram indicates that many indirect, 'autonomous', large-scale, long- 
term DFs work via intermediate stages. The nearby intermediate stage represents the changes and resulting pressure from various socio-economic sectors claiming space. Resulting changes in land use (see also Turner et al. 1995) are: change in destination (or allocation) for a specific land-use type, the related spatial lay-out and/or the intensity in management of a piece of land for a certain function or combination of functions (agriculture, recreation, housing and so on). This mental map, like the DPSIR concept, suggests neither that causality is a one-way-street affair, nor that changes in landscapes are mono-causal. Again we stress that many processes are interlinked.

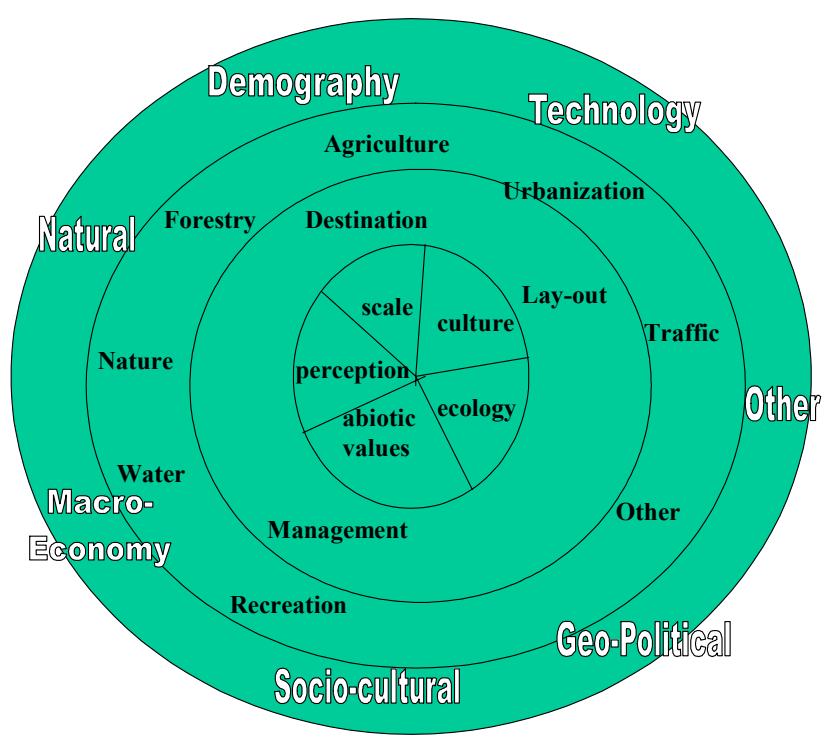

Figure 2. A mental map for landscapes

\section{Decision-making as a response}

A last useful concept is shown in Figure 3. Decision-making is considered a conscious process with a certain liberty to choose adequate weapons from the potential arsenal decision-makers have. Decision theory (Mesarovic, Macko and Takahara 1970; Haimes 1977; Saaty 1990) helps in defining the appropriate level in the hierarchy of decision-making. Free after Haimes (1977; see also Klijn 1995a) one could state that higher-level decisions i) concern a larger portion or broader aspects of overall systems, ii) have longer time horizons and concern longer-range behaviour, iii) should have priority over lower-level decisions. Winsemius and Guntram (2002) presented insights related to company strategies concerning environmental issues. We liberally adapted their stages in 'corporate response' for our goals (Figure 3). We can distinguish four approaches:

1. reactive, ad hoc, end-of-pipe, effect-oriented solutions on a low decision level complying with regulations and avoiding direct damage;

2. functional decisions (cost-effective, optimizing existing processes, fitting in investment cycles;

3. integrated (in normal strategies of relevant policy domains, taking advantage of positive interaction or win-win options, taking into account side effects of measures; and eventually 
4. proactive (vision-driven, anticipative, innovative, aimed at long-term and higherlevel goals, combining more values, such as addressed under the heading of sustainable development).

Obviously an approach-oriented at driving forces and their interactions belongs to the last category.

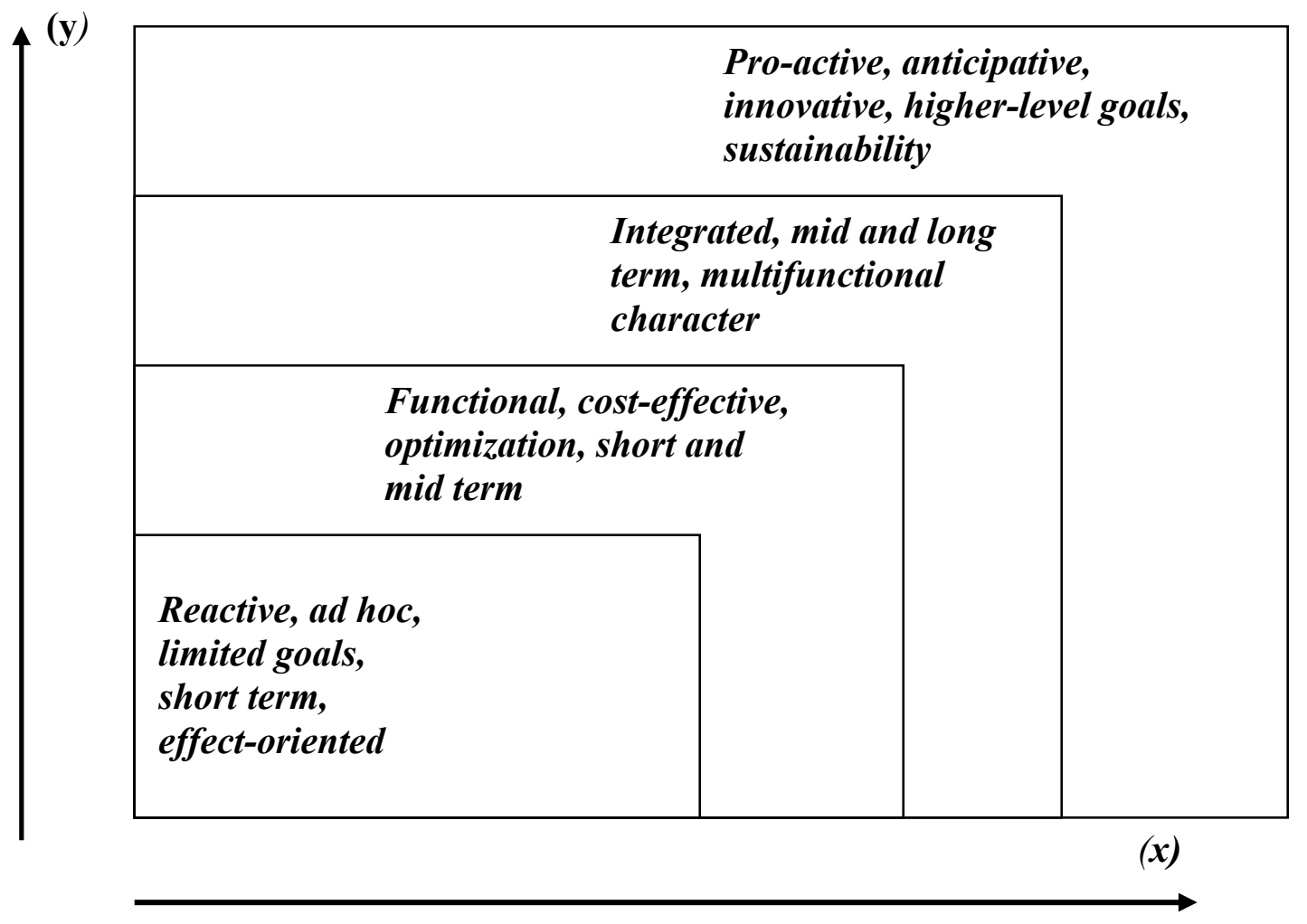

Figure 3. Classification of decision-making. $x$-axis: spatial and temporal scale; y-axis: increasing number of values and level of integration, anticipation and balance in values; various stages of decision-making and their main characteristics (largely based on Winsemius and Guntram 2002)

\section{Driving forces affecting landscapes: agriculture and climate change}

\section{Introduction}

As stated above, driving forces affecting landscapes on a European level require further specification to understand:

- their nature (how do they function, how are they interrelated with other driving forces?)

- their dynamics (direction and rate of change, possible fluctuations, how predictable?)

- their geographical extent (size of area; position within Europe?)

- their impact on landscapes and landscape values (threats or opportunities?)

- possibilities to intervene (how, when, by whom, how effective/efficient?)

Direct causes of substantial landscape changes in Europe can be divided into large clusters of urban/industrial/infrastructural changes, change in rural land use and biophysical changes perceived as natural changes.

We choose agricultural land use and global climate change as examples to illustrate the approach, while our primary interest is to identify driving forces and possibilities 
to intervene. This choice does not imply that urban sprawl and the expansion and reinforcement of transport routes are not considered important. They are not elaborated for practical reasons alone.

Agriculture is by far the most dominant land use in Europe (45\% of the area), recent and ongoing changes are fast, massive and meaningful for landscape values, and expectations for the coming decades are thrilling (OECD 2001; WRR 1992). Moreover, there is a substantial influence of (international) common agricultural policy (CAP) that is and will be subject to adjustments, partly because of the changing view on landscape values. Global change in climate is an ongoing process, well documented through empirical data, and evidently related to anthropogenic causes in the last half century, whereas its possible future impacts and its relevance for policymakers in various fields are beyond discussion. Predictions for the coming century show major changes in temperature, precipitation and other phenomena, directly or indirectly affecting large if not all parts of Europe (IPCC 2001; Parry 2000).

In both cases policy options and apt decisions on measures are subject to many debates concerning their feasibility, effectiveness and efficiency. Moreover, agricultural land-use change and global climate change are interconnected: climate change considerably affects agricultural possibilities and will influence land use accordingly. Some land use is considered to be a (minor) cause of emission of greenhouse gases, other land use (forest development, wetlands) could be effective in reducing output of greenhouse gases by storing $\mathrm{CO}_{2}$ or by delivering renewable organic fuels. Conscious adaptation of land use can furthermore be instrumental to minimize adverse hydrological effects of climate change (in case of shortage or surplus of water).

\section{Agriculture}

Agriculture in history until today

Agriculture in Europe is millennia old (Ponting 1991; 1993; Slicher van Bath 1960), and this is the main reason why European landscapes are predominantly cultural landscapes. They range from nearly completely man-made and intensively managed polders in The Netherlands to semi-natural extensive grazing areas in the high Alps. The heritage of agriculture is visible in occupation, reclamation, irrigation or drainage and related ecosystem patterns. Many witnesses of the agricultural history can be found in villages and towns in buildings used for food storage, processing and trade. Distinct changes can be related to changes in agricultural practice and techniques (e.g. introduction of the plough, artificial fertilizer), or to demographic, economic, geopolitical or natural conditions. We can distinguish several periods of contraction and expansion of the cultivated area, logically influencing the landscape (Bregt and De Zeeuw 2001; Slicher van Bath 1960; Rabbinge and Van Diepen 2000). Some figures illustrate the remarkable increase in productivity (from Bregt and De Zeeuw 2001; Rabbinge 2002).

In the beginning of the Middle Ages more than $80 \%$ of the working population was active in agriculture. Since then processes of contraction of the cultivated area are described as a result of the pest (the Black Death) causing a strong decline in population until 1400. Afterwards an increase in cultivated areas until 1800 took place. Thereafter a contraction of cultivated area has been observed due to both higher production levels and international agricultural crises (partly due to cheap import from the USA, Canada, Australia and third-world countries). This phase was followed 
again by an expansion supporting food demand from rapidly growing populations in industrializing countries.

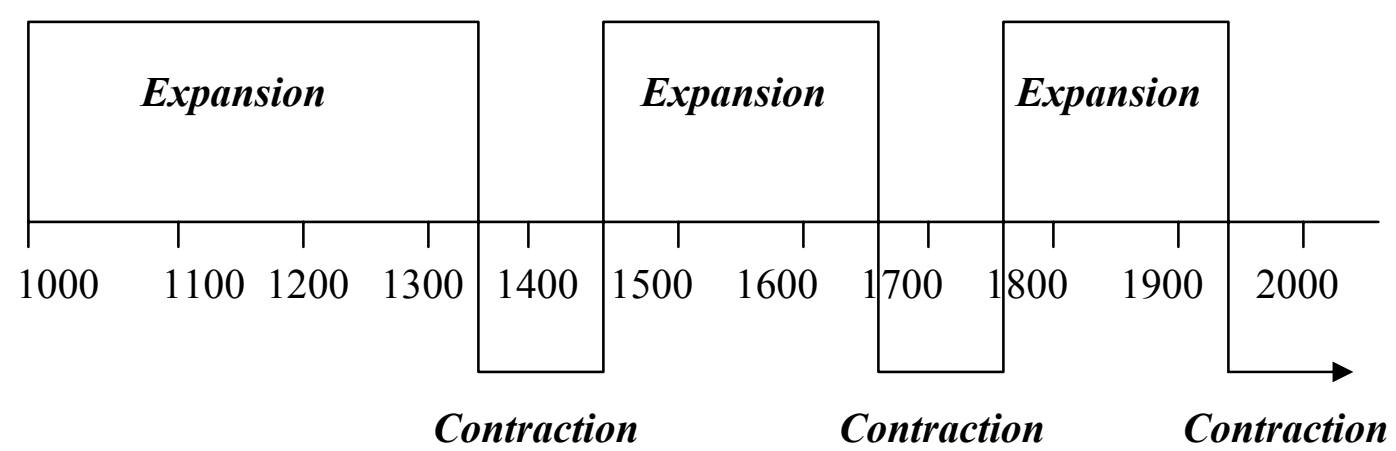

Figure 4. Expansion and contraction of cultivated area in Europe (after Rabbinge and Van Diepen 2000)

The increase in cultivated area took place as formerly poor, unsuitable soils were made suitable for farming thanks to artificial fertilizer. From 1950 on we are witnessing a contraction phase, due to a new sharp increase in yields per farm, person or hectare, and accelerated by incentives from various domains of economy (demand of labour force), society and policy (stimulating efficient, high input, cheap food production). For details on the present situation in the EU see Box 2. Some changes in agricultural history over Europe were related to climatic change affecting marginal areas or specific crop production mostly (Le Roy Ladurie 1972; Lamb 1972, 1977). In the last two centuries agricultural science, education and technology have had an increasing impact. We also see an increasing governmental interference by laws, subsidies, penalties (Klijn, Berkhout and Farjon in preparation), shifting from national to international levels (CAP).

\section{The future of European agriculture}

Recent data and predictions point to a further contraction of the agricultural area. Scenario studies were already carried out by Brouwer and Chadwick (1991) and by the Netherlands Scientific Council for Government Policy (WRR 1992). The latter authors take into account potential yields (with optimal management, nutrient availability, pest control and water availability) and predict from there an amazingly large area that can be taken out of production on the condition that a technological, economic and agronomic optimum in the most productive agro-ecological regions can be reached. Depending on the scenarios a reduction of $40-80 \%$ in agricultural area should theoretically be possible, production circumstances being optimal. Again regional differentiation is required. Potential increase in productivity per hectare and per farm is large in many Southern-, central- and Eastern-European countries. It can be expected that agriculture (as a sector as a whole or on the level of the individual farmer) could react in various ways depending on threats and opportunities (see e.g. Baldock, Beaufoy and Brouwer 1996; Bethe 1997; Klijn et al. 1999):

i) land abandonment in less favoured areas;

ii) scale enlargement (larger farms, larger parcels, loss of small-scale landscape elements such as hedgerows and dry stone walls);

iii) extensification (less input of capital and labour or of energy or fertilizer, per area or other unit in marginal conditions); 
iv) intensification (the opposite to what is seen in the most favourable areas or in agro-industrial complexes); and

v) diversification (income from other sources such as recreation and nature management or part-time jobs in towns).

Large marginal areas are expected to be abandoned sooner or later when economic sustainability would be the single criterion. It is evident that in all scenarios historical, ecological or scenic landscape features will be affected; a conclusion that might lead to stronger counteractions from politicians than already developed by various stages in the CAP (Common Agricultural Policy for Europe).

\title{
Box 2. Some key figures on agriculture in Europe
}

\begin{abstract}
History shows an incredible and seemingly irreversible expulsion of labour over time. Rabbinge (2002) compared the output for wheat around $1400 \mathrm{AD}$ with the current situation: in 1400 some $800 \mathrm{kilogram} / \mathrm{ha}$ was harvested thanks to 700 hours of labour against $1800 \mathrm{~kg} / \mathrm{ha}$ thanks to 350 hours around 1900 and $9000 \mathrm{~kg} / \mathrm{ha}$ in $8-15$ hours of labour today. Productivity per hour increased between 500 and nearly 1000 times! Of course these leaps in productivity led to upscaling processes, still going on in modern decades. Between 1966 and 1997 the average farm size in all EU-15 countries doubled (data from Eurostat 2000). The percentage of farmers in the working force in EU countries strongly decreased, a process still continuing. Between 1965 and 1985 the number of farmers of the $12 \mathrm{EU}$ countries decreased from 15 million to 8 million, a decrease from $17 \%$ to $6 \%$ of the work force. The average in the late nineties for the EU15 countries is 5\%. Again we see large differences: Greece counts $20 \%$ employment in agriculture, the UK only $2 \%$. Recent changes in cultivated area point to a considerable shrinking of agricultural land: in average for the EU-15 countries between 1985/7 and 1995/7 a decrease of 5\% took place, again with distinct differences between European states: Ireland had more than $10 \%$ decrease, Norway an increase of $3 \%$ (all data from OECD 2001). In view of an ageing farmer population and poor perspectives a further decrease is highly probable. This applies to both EU-15 countries and new-accession countries, where agriculture still is an important sector, such as Poland (above 60\% of the area is in agricultural use; its share in Gross Domestic Production is 7\% (twice the average of EU-15) and about $19 \%$ of labour is related to agriculture. Nowadays, nearly half of the area (45\%) of the EU-15 countries is cultivated (Eurostat 2001; OECD 2001), although large differences between European countries emerge: in Norway (not within the EU) less than 5\% due to physical constraints such as the lack of soils, steep slopes or unfavourable climate conditions, in the UK more than 70 .
\end{abstract}

\section{DFs affecting agriculture identified}

When looking at the DFs as indicated in Figure 2, change in agriculture is evidently driven by a complex of factors including biophysical processes (e.g. climate change), demography (determining the need of food and the availability of labour; partly influenced by diseases), geopolitical change (e.g. the formation of the EU), the accession of former central- and Eastern-European countries, the combined push from knowledge and technology resulting in the uncanny rise in yields known as the Green Revolution, the pull and sometimes push from other economic sectors (industrialization demanding labour) and not least the influence of national and international policy on agriculture or world trade (CAP respectively WTO). As can be seen from the Netherlands (Klijn, Berkhout and Farjon in preparation) interventions by national administrations were prominent during major agricultural crises in the last century in order to guarantee food supply on the long term and to retain labour in agriculture, whereas other economic sectors were on their retreat between World 
Wars I and II. Afterwards the opposite trend was stimulated by the then governments; there was an intensive reconstruction of agriculture pushed and partly financed by national and international governments in order to provide jobs in industry and trade while safeguarding cheap food. It underlines the observation that policy and related regulations themselves can be seen as a driving forces. As is well known, agricultural policy underwent important upscaling processes as important agreements are made on EU level (CAP) and even world level (WTO). The agricultural and food sector organized itself more and more on an international level (multinationals, globalization). Technology in agriculture has always been an outstanding key factor bringing about major changes in plant and animal breeding, mechanization, transport, and farm management. It influences the complete chain from seed to end product. Governments invested in (applied) agricultural science and education programmes to support innovation processes and higher productivity. Rather recently a change in perception and life style can be seen as a DF on its own, belonging to the sociocultural domain as shown in Figure 2. For example, in The Netherlands in recent decades there has been a distinct change in attitude towards farming and farmers. Confronted with environmental, ecological and ethical drawbacks of modern, highintensity farming the attitude towards the role of agriculture in society changed drastically. Hardly critical consumers of cheap food became more critical towards food quality, quality of production processes, environment and landscape qualities. Agriculture as a sector, as perceived in some countries, should earn its 'licence to produce'. Synchronously citizens demand larger areas for housing, recreation, nature restoration and other goals. As the majority of people is beginning to lose their roots in a once agricultural society one can observe a lack of goodwill and understanding towards agriculture and farmers. Such a process of alienation can include a lack of awareness of the qualities of agricultural landscapes (Vos and Klijn 2000).

\section{Conclusions related to intervention possibilities}

Agriculture is an almost omnipresent, large-scale user of landscapes largely responsible for its present day cultural and ecological features and values. Whatever its future in the nearby decades, landscapes will be affected. Transitions are driven by a complex of processes in demography, geopolitics, macro-economy, technology. Socio-cultural changes seem to grow in importance, the more so when basic needs of food are satisfied. Climate changes had repercussions in history; their importance can increase in view of predicted global change. The role of national and international governments or international agreements has been important in the last century or more. Their influence should not be underestimated, as this is not limited to agriculture as such, but also affecting other domains. Sometimes governmental policies form a driving force themselves, and this is a reason why the desired and undesired outcomes of a certain policy should be assessed very well. The recognition of the problem of vanishing cultural landscapes and the will to include landscape goals in various policy domains in a proactive and efficient way are crucial. It seems that public support is available, that policy tools are present but that co-ordination in goal-setting, policy formulation and effective implementation is still less effective. Current EU policy (since the major McSharry reform in 1992) and measures under construction are intended to take into account landscape values but need to be fortified in several ways (Hoogeveen, Petersen and Gabrielsen 2002):

- enlargement of the budgetary proportion for landscape, bio-diversity and environment, 
- discouraging unsustainable intensification of agriculture (stimulated by agricultural and other policies),

- encouraging production of regional specialities,

- a better co-ordination between agricultural policy with adjacent policy fields such as environment, spatial planning or water management on watershed level (European Water Directives) and

- being on the alert what side-effects the neo-liberal WTO agreements could have on European landscape assets and launching effective counteractions or even reconsidering such agreements more fundamentally.

\section{Climate change and sea-level rise}

From natural to man-induced forces changing the climate

There is abundant literature on the variability of climate in geological or historical time frames (e.g. Lamb 1972, 1977; Gajewski 1987; Bradley and Jones 1993) showing remarkably fast fluctuations superposed on longer fluctuations. Explanations of these phenomena include many factors of astronomical origin, volcanism, shifts in major ocean currents and other factors including the history of land use. Natural DFs seemed to prevail until in the twentieth century a worldwide and substantial increase in greenhouse gases basically changed the energy household in the atmosphere and on the earth's surface. Climate change as a man-induced phenomenon is beyond theoretical discussions questioned by unwilling politicians. Real changes in temperature (increase of $0.6^{\circ} \mathrm{C}$ in the Northern Hemisphere) and in precipitation distribution have been observed during in the last century. Climate change and the substantial contribution of man-induced changes are scientifically and politically accepted as a fact. Predictions of further change in the coming century are considered very plausible and serious enough to take measures (IPCC 2001). The outlook implies a significant increase in global temperature $\left(1.4-5.8^{\circ} \mathrm{C}\right.$ in a century, depending on scenarios of population growth and economic development) and a meaningful shift in precipitation patterns. Expectations for Europe are e.g. an increase in winter (5-20\%) and summer $(<10 \%$ increase) precipitation in northern regions, and a decrease in summer precipitation in southern regions of more than $20 \%$. Sea-level rise results from melting land-based ice and the expansion of water in oceans. Predictions for the coming century are $0.09-0.88 \mathrm{~m}$ sea-level rise, apart from regional differences due to uplift or subsidence. It has to be stressed that both the predicted amounts of sea-level rise and its rate exceed changes in our history. The adaptive capacity of society to react in a proactive and anticipating way can be doubted. Very relevant is that many effects of climate change, such as sea-level rise manifest themselves with great delay due to time lag mechanisms.

\section{Effects on landscapes}

Global change in climate will affect the larger part of Europe's landscapes (Parry 2000; Beniston and Tol 2001; Watson et al. 2001), either directly (deglaciation, desertification, increase in river discharge in winter and spring but also lower summer discharges, effects on aquifers, shift in bio-zones, coastal erosion) or via changes in land use. Glaciers and permanent snow masses will disappear from high mountains (estimated loss between 50 and 90\%) causing decline in alpine tourism. Permafrost areas will disappear largely from northern territories. Forest areas will regionally suffer more frequently from forest fires. Flooding risks in river valleys and other lowlying areas following peaks in precipitation will further increase. Water supply for major urban areas will be affected negatively. Where sea-level rise and/or increased 
coastal erosion is expected certain 'soft' coastal areas, such as deltas, estuaries, dune areas and salt marshes can be classified as extremely vulnerable (Klijn 1990; 1995b; Jelgersma and Tooley 1992). Salt intrusion results from higher sea level and lower summer discharge from rivers, and the effects are reinforced by higher water demands for (irrigated) agriculture. From this short overview it emerges that larger areas in Europe will undergo major changes in climate affecting either directly landscape features or indirectly by changing land use adapting itself to the new situation. Agriculture for instance will have to adapt itself especially in Mediterranean areas where rain-fed agriculture will suffer severe droughts, where irrigated areas will consume more sparse water or have to be abandoned. In deltas or coastal lowlands salt intrusion can be expected, in Eastern Europe larger semi-arid areas are susceptible to salinization. In Scandinavia and other northern areas one could expect more possibilities for agriculture. Agro-ecological zones will shift, meaning a shift in agricultural use (crops, husbandry and horticulture). As an example: the winter-wheat production zone is thought to move to the north by $90 \mathrm{~km}$ per ${ }^{\circ} \mathrm{C}$ warming. In total this could lead to $400,000 \mathrm{~km}^{2}$ 'new' area suitable for winter wheat. Estimates for potato and grapevine predict both higher and lower yields according to the predicted climate scenarios for a certain region (Harrison, Butterfield and Gawith 1995). Overall, thanks to higher temperature and higher $\mathrm{CO}_{2}$ concentrations, higher yields are to be expected, adding to the production potential and to the possibilities or necessity to abandon the least productive areas. These and other direct and indirect effects of climate change, including all interactions with agricultural land use, will result in major changes in landscape features and related values in most if not all landscapes. Specification is needed for climatic regions, landscape types and land-use systems involved: alpine regions will experience deglaciation, higher rainfall and erosion, whereas Mediterranean countries will have to face imminent effects of long summer droughts in rain-fed agriculture on public water supply, increased erosion or the danger of salinization of irrigated areas.

\section{Driving forces and intervention possibilities}

Driving forces are partly natural, for a major part related to man's impact, caused by population growth and the unchecked use of fossil energy driven by expanding economies and technology. Evidently man-induced disturbance of the global energy household, leading to many adverse and some positive effects, requires action on various levels. Urgent global source-oriented action aimed at emission reduction is indisputable. Possibilities to intervene have been subject of international conferences and agreements (e.g. Rio de Janeiro, Kyoto and Johannesburg). Notwithstanding the legitimacy and urgency of global agreements, doubts on their timely implementation and positive effects are justified: international agreements on goals and measures are notably hard to accomplish for political, social and technical or economic reasons and will take considerable time so that, when measures will eventually succeed, one has to accept serious delays in results. Some adverse effects will therefore be inescapable. Decision-makers will have to accept complementary, e.g. spatial planning strategies that are effect-oriented rather than source-oriented. Taking sea-level rise as an example: integrated spatial-planning measures should help to avoid building near vulnerable coasts to avoid expensive sea-defence works. Even a flexible retreat could be more effective and efficient than investing in costly sea-defence works. Comparable dilemmas can be seen when river-related risks are at stake. It is evident that the nature and spatial and temporal scale of global change and its driving forces ask for interventions on various levels: powerful international long-term actions 
aimed at the worldwide reduction of greenhouse gases, sustained by regional strategies to store carbon dioxide in ecosystems (marshes, forests) and all technical means to reduce consumption of fossil fuels. Regional or local (spatial) measures on a mid-term time scale that help to avoid or minimize new risks (flooding, erosion) by prudent spatial planning and local, relatively short-term measures to prevent hazards (coastal protection) in urgent cases could be supplementary. In general, we could imagine a mix of long-term, mid-term and short-term strategies on various scales exploiting the full arsenal of technical, spatial and other measures. To do this in an efficient manner a high level of integration and co-ordination between the various policy domains and administrative levels is required. The paramount challenge will be to convince interest groups what the risks and the cost and benefits are of a 'proactive' attitude instead of ad-hoc responses. There are good reasons to give more attention to the possibilities for incorporation of knowledge and ideas in regional and national physical-planning strategies that seem to represent an efficient level of decisions in view of the imminent problems. As adequate strategies need fine-tuning to regional circumstances and a conscious choice of a possible arsenal of measures, sufficient knowledge is a key factor to accomplish an efficient and effective strategy. As various target groups in different regions have to be approached a well-documented risk map of Europe accompanied by a set of effective measures on various scale levels and their relative contribution in solving the problems would be instrumental.

\section{Discussion and conclusions}

\section{General}

Returning to the key question asked at the outset of this contribution: could landscape policy benefit from a better insight in driving forces and a more strategic, proactive role of decision-makers? Posing the very question starts from the assumption that policy-making and implementation make a difference. Though pessimistic views are abundant, we start from an optimistic viewpoint:

- Governments, NGO's and the larger and more responsible commercial parties seriously try to act from a socio-cultural, economic or ecological point of view (the well-known triangle with People, Profit, Planet), thus encompassing common goods.

- One can observe a gradual up-scaling in sciences, public awareness and policymaking and implementation trying to keep pace with the up-scaling of driving forces.

- One can incidentally observe a significant role of policy making in various fields.

One example of the latter is the agricultural policy in Europe in the last half of the 20th century, regardless of its undesired trade-offs. Our angle of view is that an integrated and coherent effort on a European level can make quite a difference.

\section{Concepts}

- The idea of DFs helps to understand what underlying processes are basically responsible for landscape changes and where options for interventions can exist.

- The DPSIR concept and the 'mental map' for landscape change help to clarify mechanisms involved.

- Decision theory and the identification of decision-making in distinct stages can be helpful to make conscious choices.

- The main question is whether interventions can be more proactive, effective and efficient and fit within the span of control of decision-makers. 


\section{Major DFs in Europe}

- Main domains of DFs can be found in demography, macro-economy, geopolitics, technology, socio-cultural aspects (attitude and behaviour) and sometimes global change (climate, sea-level rise). The effect of policy-making can however be regarded as a DF on its own. Historical studies can reveal the importance and dynamics. Many of these driving forces act in combination.

- For Europe and related landscape values, important driving forces can be expected from climate change and changes in agriculture (together with urban and infrastructural sprawl).

\section{Policy implications}

Thoughts on policy-making can be recapitulated as:

- The intensity of DFs and related changes in land use are different for regions within Europe, as well as their effect on landscape values: regional specification is compulsory.

- Effective policy-making and implementation requires a strong co-ordination; as many DFs act by nature or due to changes in political and economic constellation on a higher scale (international or even global) the span of control and power of administrations should be brought in balance.

- A combination of strategies varying from proactive to more effect-oriented shorttime measures will often be necessary, depending on the urgency of the problem and political 'facts of life'.

- For changing land use, more specifically agriculture, EU policy-making can be decisive for a sustainable conservation and restoration of landscape values. Policy orientation should involve landscape values more than now, a widening of scope and goal-setting ('green services', biodiversity, climate control, biofuels). Coordination with other (national) policy fields creates more opportunities and momentum than an approach limited to partial solutions.

- Climate change and sea-level rise are long-term, global processes that need to be addressed radically in their underlying causes. Time lag in accomplishing such a strategy is unavoidable, so that there is a need to mitigate effects by second-best strategies. A restructuring of land use (destination, lay-out, management) should be effective and efficient. This helps to create a more sustainable spatial organization that could cope with mid-term effects of water-related aspects (shortage and surplus of water) and enhance possibilities to contribute to less emission of greenhouse gases (organic fuel; storage of carbon dioxide).

\section{Further research}

These concepts and thoughts and concepts will surely influence the European research agenda. Many aspects have only been touched upon; we propose further research on the following themes:

- how to define the relationships between various spatial scale levels: what processes emerge, on what scale are appropriate decisions / measures relevant?

- to make GIS systems and derived maps of various landscape aspects available, including their response / specific vulnerability to changes in land use or change in climate, urbanization processes

- to promote scenario studies including procedures (back-casting methods) to design a spatial lay-out offering a geographical distribution of land use and nature that is robust in view of predicted changes. 


\section{Acknowledgements}

The author is grateful to Prof. R. Rabbinge (Wageningen University and Research Centre, The Netherlands) and Dr. M. Bürgi (Eidgenossische Forschungsanstalt WSL, Birmensdorf, Switzerland) for their useful comments on an earlier version and to Dr. R.H.G. Jongman for editorial advice.

\section{References}

Baldock, D., Beaufoy, G. and Brouwer, F. (eds.), 1996. Farming at the margins: abandonment and redeployment of agricultural land in Europe. London, Institute for European Environmental Policy IEEP.

Beniston, M. and Tol, R.S.J. eds., 2001. Europe. In: Watson, R.T., Zinyowera, M.C., Moss, R.H., et al. eds. The regional impacts of climate change: an assessment of vulnerability. Cambridge University Press, Cambridge, Ch. 5. Special Report of IPCC Working Group II. [http://www.grida.no/climate/ipcc/regional/091.htm]

Bennett, G. (ed.) 1994. Conserving Europe's natural heritage: towards a European ecological network: proceedings of the international conference held in Maastricht, 9-12 November 1993. Graham and Trotman, London.

Bethe, F. (ed.) 1997. Rural areas and Europe: processes in rural land use and the effects on nature and landscape. Ministry of Housing, Spatial Planning and The Environment, The Hague.

Bradley, R.S. and Jones, P.D., 1993. "Little ice age" summer temperatures variations: their nature and relevance to recent global warming trends. The Holocene, 3 (4), 367-376.

Bregt, A.K. and De Zeeuw, C.J., 2001. Agriculture, forestry and nature: trends and developments across Europe. In: Stillwell, J. and Scholten, H. eds. Land use simulation for Europe. Kluwer, Dordrecht, 37-44.

Brouwer, F.M. and Chadwick, M.J., 1991. Future land use patterns in Europe. In: Brouwer, F.M., Thomas, A.J. and Chadwick, M.J. eds. Land use changes in Europe. Kluwer, Dordrecht, 49-78. Geojournal Library no. 18.

Chorley, R.J. and Kennedy, B.A., 1971. Physical geography: a systems approach. Prentice-Hall, London.

Council of Europe, 1996. The Pan-European Biological and Landscape Diversity Strategy (PEBLDS). Council of Europe, Strasbourg. [http://www.nature.coe.int/english/main/strategy/PBLDS/text.htm]

Council of Europe, 2001. The European Landscape Convention and its explanatory report. Council of Europe, Strasbourg.

[http://www.nature.coe.int/english/main/landscape/conv.htm]

Delbaere, B.C.W. (ed.) 1998. Facts and figures on Europe's biodiversity: state en trends 1998-1999. European Centre for Nature Conservation ECNC, Tilburg. ECNC Technical Report Series.

Delcourt, H.R. and Delcourt, P.A., 1988. Quaternary landscape ecology: relevant scales in space and time. Landscape Ecology, 2 (1), 23-44. [http://landscape.forest.wisc.edu/landscapeecology/Articles/v2i1p23.pdf]

EEA, 1998. Europe's environment: the second assessment. European Environment Agency EEA, Copenhagen. 
EEA, 2002. Environment signals 2002: benchmarking the Millennium. European Environment Agency EEA, Copenhagen. Environmental Assessment Report no. 9 .

[http://reports.eea.eu.int/environmental_assessment_report_2002_9/en/tab_con tent_RLR]

Eurostat, 2001. Eurostat Yearbook 2001. Office for Official Publications of the European Communities, Luxembourg.

Gajewski, K., 1987. Climatic impacts on the vegetation of Eastern North America during the past 2000 years. Vegetatio, 68, 179-190.

Haimes, Y.Y., 1977. Hierarchical analyses of water resources systems: modeling and optimization of large-scale

systems. Mc Graw-Hill, New York.

Harrison, P.A., Butterfield, R.E. and Gawith, M.J., 1995. Modelling the effect of climate change on crops at the regional scale: effects on winter wheat, sunflower, onion and grassland in Europe. In: Harrison, P.A., Butterfield, R.E. and Downing, T.E. eds. Climate change and agriculture in Europe: assessment of impacts and adaptation. University of Oxford, Oxford, 330-385. Research reports Environmental Change Unit no. 9.

Hoogeveen, Y.R., Petersen, J.E. and Gabrielsen, P., 2002. Agriculture and biodiversity in Europe. Council of Europe, UNEP, Strasbourg. STRACO/AGRI (2001) 17. [http://www.coe.int/t/e/Cultural_Cooperation/Environment/Nature_and_biological_diversity/biodiversity/agri17e. 01-1.pdf]

IPCC, 2001. Third assessment report: climate change 2001. Cambridge University Press, Cambridge.

Jelgersma, S. and Tooley, M.J., 1992. Impacts of a future sea level rise on European coastal lowlands. In: Tooley, M.J. and Jelgersma, S. eds. Impacts of sea-level rise on European coastal lowlands. Blackwell, Oxford, 1-36. The Institute of British Geographers Special Publication Series no. 27.

Klijn, J.A., 1990. The younger dunes in the Netherlands: chronology and causation. In: Bakker, T.W., Jungerius, P.D. and Klijn, J.A. eds. Dunes of the European coasts: geomorphology-hydrology-soils. . Catena Suppl.18: 81-89. Catena supplement no. 18.

Klijn, J.A., 1995a. Hierarchical concepts in landscape and its underlying disciplines: the unbearable lightness of a theory? DLO-Staring Centrum, Wageningen. Report / DLO-Staring Centrum no. 100.

Klijn, J.A., 1995b. Scenarios for European coastal areas: a promising tool for making decisions at various levels? In: Schoute, J.T.H., Finke, P.A. and Veeneklaas, F.R. eds. Scenario studies for the rural environment: selected and edited proceedings of the symposium scenario studies for the rural environment, Wageningen, The Netherlands, 12-15 September 1994. Kluwer, Dordrecht, 457-471. Environment \& Policy no. 5.

Klijn, J.A., Berkhout, P. and Farjon, J.M.J., in preparation. Motoren achter landschapsveranderingen. Alterra, Wageningen.

Klijn, J.A., Bethe, F., Wijermans, M., et al., 1999. Landscape assessment methodology on a European level: polder landscapes as an example. The Winand Staring Centre, Wageningen.

Klijn, J.A. and Vos, W., 2000. From landscape ecology to landscape science: proceedings of the European congres "Landscape ecology: things to do proactive thoughts for the 21st century", organised in 1997 by the Dutch 
Association for Landscape Ecology (WLO) on the occasion of its 25th anniversary. Kluwer, Dordrecht.

Lamb, H.H., 1972, 1977. Climate: present, past and future. 2 Vol. Methuen, London.

Le Roy Ladurie, E., 1972. Times of feast, times of famine: a history of climate since the year 1000, London.

Meeus, J.H.A., Wijermans, M.P. and Vroom, M.J., 1990. Agricultural landscapes in Europe and their transformation. Landscape and Urban Planning, 18 (3/4), 289-352.

Mesarovic, M.D., Macko, D. and Takahara, Y., 1970. Theory of hierarchical, multilevel systems. Academic Press, New York. Mathematics in Science and Engineering no. 68.

OECD, 1994. OECD core set of indicators for environmental performance reviews: a synthesis report. Organisation for Economic Co-operation and Development OECD, Paris. OECD Environmental Monographs no. 83.

OECD, 2001. Environmental indicators for agriculture. Organisation for Economic Co-operation and Development OECD, Paris.

Parry, M. (ed.) 2000. Assessment of potential effects and adaptations for climate change in Europe: scenarios of climate change for Europe: the Europe Acacia Project (a concerted action towards a comprehensive climate impacts and adaptations assessment for the European Union). University of East Anglia, Jackson Environment Institute, Norwich.

Pedroli, B. (ed.) 2000. Landscape, our home: essays on the culture of the European landscape as a task = Lebensraum Landschaft: essays über die Kultur der Europäischen Landschaft als Aufgabe. Indigo, Zeist.

Ponting, C., 1991. A green history of the world. Penguin Books, London.

Ponting, C., 1993. A green history of the world: the environment and the collapse of great civilizations. Penguin, New York.

Posch, M., Hettelingh, J.P. and De Smet, P.A.M., 1997. Calculation and mapping of critical thresholds in Europe: status report 1997. RIVM, Bilthoven. RIVM report no. 259101007.

Rabbinge, R., 2002. Duurzaamheid en duurzame ontwikkeling. Wageningen Universiteit, Wageningen. [http://www.wau.nl/pers/01/rabbinge01.doc]

Rabbinge, R. and Van Diepen, C.A., 2000. Changes in agriculture and land use in Europe. European Journal of Agronomy, 13 (2/3), 85-99.

Saaty, T.L., 1990. The Analytic Hierarchy Process (AHP): how to make a decision. European Journal of Operational Research, 48 (1), 9-26.

Slicher van Bath, B.H., 1960. De agrarische geschiedenis van West-Europa 5001850. Spectrum, Utrecht.

Turner, B.L., Skole, D., Sanderson, S., et al., 1995. Land-use and land-cover change: science research plan. International Geosphere-Biosphere Programme IGBP, Stockholm. IGBP Report no. 35.

Vos, W. and Klijn, J., 2000. Trends in European landscape development: prospects for a sustainable future. In: Klijn, J. and Vos, W. eds. From landscape ecology to landscape science. Kluwer, Dordrecht, 13-30.

Wascher, D.M. (ed.) 2000. Agri-environmental indicators for sustainable agriculture in Europe. European Centre for Nature Conservation ECNC, Tilburg. ECNC Technical Report Series.

Watson, R.T., Zinyowera, M.C., Moss, R.H., et al. (eds.), 2001. The regional impacts of climate change: an assessment of vulnerability. Cambridge University 
Chapter 14

Press, Cambridge. Special Report of IPCC Working Group II. [http://www.grida.no/climate/ipcc/regional/index.htm]

Winsemius, P. and Guntram, U., 2002. A thousand shades of green: sustainable strategies for competitive advantage. Earthscan, London.

WRR, 1992. Ground for choices: four perspectives for the rural areas in the European Community. SDU, The Hague. Reports to the Government no. 42. 